Review

\title{
The State of the Art of Material Flow Analysis Research Based on Construction and Demolition Waste Recycling and Disposal
}

\author{
Dongming Guo * (D) and Lizhen Huang \\ Department of Manufacturing and Civil Engineering, Norwegian University of Science and Technology, \\ 2802 Gjovik, Norway; lizhen.huang@ntnu.no \\ * Correspondence: dongming.guo@ntnu.no; Tel.: +47-925-59-641
}

Received: 9 August 2019; Accepted: 18 September 2019; Published: 21 September 2019

\begin{abstract}
Construction and demolition waste (C\&D waste) are widely recognized as the main form municipal solid waste, and its recycling and reuse are an important issue in sustainable city development. Material flow analysis (MFA) can quantify materials flows and stocks, and is a useful tool for the analysis of construction and demolition waste management. In recent years, material flow analysis has been continually researched in construction and demolition waste processing considering both single waste material and mixed wastes, and at regional, national, and global scales. Moreover, material flow analysis has had some new research extensions and new combined methods that provide dynamic, robust, and multifaceted assessments of construction and demolition waste. In this paper, we summarize and discuss the state of the art of material flow analysis research in the context of construction and demolition waste recycling and disposal. Furthermore, we also identify the current research gaps and future research directions that are expected to promote the development of MFA for construction and demolition waste processing in the field of sustainable city development.
\end{abstract}

Keywords: Material flow analysis (MFA); construction and demolition waste (C\&D waste); recycling and reuse; environmental impact

\section{Introduction}

The construction and operation of buildings occupy almost $40 \%$ of the depletion of natural resources and $25 \%$ of global waste [1,2]. Construction and demolition waste has become a major source of urban waste and usually accounts for 10-30\% of the total waste landfilled [3]. In the European Union (EU), construction waste occupies more than $30 \%$ of the total solid waste [4]. It has been widely noticed that construction and demolition waste (C\&D waste) has been a vital issue in sustainable city development [5-8]. C\&D waste recycling and disposal has received extensive attention from academia, the construction field, and government sectors. Some international and government departments have done extensive work and have set some goals to reduce and recycle C\&D waste. For example, The United Nations SDG (Sustainable Development Goals) Goal 11 mentions waste management and Goal 12 points to substantially reducing waste generation through prevention, reduction, recycling, and reuse. Additionally, the EU Waste Framework Directive has set a target at recycling 70\% of non-hazardous C\&D waste by 2020.

However, the recycling and reuse of C\&D waste still has some barriers. One of the barriers is that the $C \& D$ waste can include a broad range of materials and the quantitative primary data is not available in some cases [9]. Accurate estimation about quantities of various kinds of construction waste from a building projects is a prerequisite and a critical factor in successful construction waste management [10]. Material flow analysis (MFA) can quantify materials flows and stocks and is 
beneficial for the analysis of waste processing. Therefore, the MFA approach has been widely adopted in the quantitative evaluation of C\&D waste recycling and disposal [11-13]. For example, material flow analysis has been used in the European waste management system, which includes construction and demolition waste processing [14]. The analysis of municipal solid waste recycling processes sometimes depends on the MFA method $[15,16]$. Moreover, a sound waste management and recycling system requires a good interpretation about the regulatory framework and the changing environmental implications, and MFA is a good tool to help implement this [17]. MFA also plays an important role in the development of planning and strategies in waste management [12]. In the new emerging economies, the new environmental policies and taxation could be proposed based on evidence from MFA [17]. In recent years, MFA has had some new developments and extensions to provide dynamic, robust, and multifaceted assessment results [18-20]. Material flow usually contains certain time and space scales. When faced with a dynamical and long-term period, dynamic material flow analysis (DMFA) is generally adopted to quantify materials stocks and flows $[19,21,22]$, such as European copper flows [23], timber quantity from 2012 to 2100 [24], and strategic construction and demolition waste management [19]. Additionally, the integration between MFA and its spatial distribution can describe a broader scale of materials social usage and is beneficial for sustainable strategic planning [25] because this integration provides a basis for the formulation of a sustainable development strategy [26]. Furthermore, MFA has been deeply regarding the processing and management of C\&D waste from a single waste material [27] and mixed wastes [28], and at regional [18,29], national [28,30], and global scales [31]. For a multifaceted assessment, MFA is combined with other analytical tools and optimal methods. The combination of MFA and Life Cycle Assessment (LCA) can accurately calculate embodied carbon or carbon emissions, and track material flows, which is helpful for estimating the potential impacts of the changes of urban metabolism $[2,18,32,33]$. An integration framework of MFA and LCA is presented to assess the potential impacts of concrete recycling and metabolism [18]. In some studies, the cost of recycling and reuse of building materials is also considered as an important factor [11,34]. Dahlbo et al. combined MFA, LCA, environmental life cycle costing (ELCC), and best available technology (BAT) approaches to assess the performance of the C\&D waste management system [11]. Beyond all that, there are some other combinations for $C \& D$ waste processing, such as MFA combined with statistical analysis [35], MFA combined with eco-balancing methods [36], MFA combined with input-output analysis (IOA) [2,37], and so on. Although some C\&D-waste-related review articles can be found, such as quantifying C\&D waste [38,39], C\&D waste management [40-43], and sustainable assessment of construction materials [44], a comprehensive analysis and summary about the state of the art of MFA based on C\&D waste is required. In this paper, we will review the development of MFA based on C\&D waste and comprehensively analyze and summarize research results.

Our contributions include: (1) analyzing the main academic research articles in academic databases and classifying them into three categories: traditional MFA, extension MFA, and combination MFA; (2) comparing and summarizing related articles about research methods, research objects, and application scopes to verify the research progress and results; and (3) identifying the current research gaps and potential future research directions. We also provide some summarized support to promote the development of MFA for C\&D waste in the field of sustainable city development.

Following this introduction section, in Section 2, research methodology will be presented. Section 3 shows some analysis results and summarizes MFA development based on C\&D waste in detail, while Section 4 provides some conclusions. 


\section{Research Methodology}

For this systematic review of MFA research based on C\&D waste, ("demolition waste" OR "building waste" OR "construction waste") AND ("material flow analysis" OR MFA) was chosen as the keywords for the topic and searches in Web of Science Core Collection, Scopus database, and Engineering Village database. The return results provided 36 articles in the Web of Science core databases, 40 in Scopus, and 31 in the Engineering Village database. After deleting some unfound full-text, non-English, duplicated, and unrelated articles, 28 articles were kept. These articles can be classified into three categories according to their employed methods, including traditional MFA, extension MFA, and combination MFA, as listed in Table 1. From Table 1, the combination MFA was most popular method for $C \& D$ waste recycling and disposal because it can provide multidimensional evaluation and analysis. An interesting finding was that all listed articles were from after the year 2000, although MFA was first proposed in 1970s. In 28 studies, there was one review paper about $C \& D$ waste quantification, in which Hassan et al. [39] reviewed the research on waste quantification in construction sites. In the next section, we will analyze and summarize the 27 articles in detail, but our discussion is not limited to these 27 papers.

Table 1. 28 An overview of 28 articles classified according to their models and methods.

\begin{tabular}{ccc}
\hline References & Main Models and Methods & Number of References \\
\hline$[10,14,17,27,28,30,31,45-47]$ & Material flow analysis (MFA) & 10 \\
\hline$[19,22,24,25,48,49]$ & Extension MFA & 6 \\
\hline$[2,11,18,35-37,50-54]$ & Multi-Method Combination MFA & 11 \\
\hline$[39]$ & Review Literature & 1 \\
\hline
\end{tabular}

\section{MFA Research Based on C\&D Waste Recycling and Disposal}

\subsection{Traditional MFA Method}

MFA can quantify material flows and stocks, so it is always used to analyze a specific waste material. For example, as for metal waste materials, Bertram et al. utilized MFA to quantify copper contents in different solid waste and identify the relevance of multiple waste streams within the copper life cycle [14]. The results showed that copper recycling had theoretically high recovery rates through appropriate technology and the right waste streams; however, because of uncertainties in waste generation and composition, more information about the waste's sources of copper is needed for building sensible strategies [14]. Chong et al. developed a comprehensive framework, using MFA, to assess and calculate the transportation energy used for steel recycling at the design stages of construction [27]. Their MFA framework ensured more accurate energy estimates by describing how materials flow during the extraction, manufacturing, transportation, and installation phases, and thus enabling construction stakeholders to better understand the sustainable material supply chain network [27]. As for non-metal waste materials, cement and concrete waste are the main research objects. Lockrey et al. pointed out that developing countries pay less attention to formal recycling systems and those similar systems replicated from developed nations [47]. Hence, they presented the practical challenges of recycling the C\&D waste in Vietnam and adopted MFA to analyze material flows and recycling rates, and as a result, they identified existing recycling logistical bottlenecks [47]. Another similar study was conducted by Tangtinthai et al. [17], in which a comparative MFA between Great Britain and Thailand regarding cement/concrete materials had been proposed to analyze the different practices of the two countries. Also at the country level, Kapur et al. developed a cement stock and flow model based on MFA to construct the American contemporary cement cycle and pointed out that control of the rapid growth of C\&D waste desperately required the joint efforts of all relevant stakeholders to minimize the amount of C\&D waste disposed in landfills [30]. Cochran et al. utilized MFA to assess C\&D cement debris generation and composition in the USA and found 
the MFA approach would benefit from the accurate estimation regarding the portion of raw material utilization and wastage during the product manufacturing stage [45]. We summarize some articles in Table 2 and list their research purposes, research objects, and research locations to better analyze and compare relevant articles.

Table 2. Summary and analysis of C\&D waste processing based on traditional MFA.

\begin{tabular}{|c|c|c|}
\hline Purpose and Description & Research Object & Location \\
\hline $\begin{array}{l}\text { Authors goals were to quantify waste generation rates and } \\
\text { copper contents to appraise the correlation of waste streams in } \\
\text { the copper life cycle [14]. }\end{array}$ & Copper & Europe \\
\hline $\begin{array}{l}\text { Based on the framework of MFA, a national stock and flow } \\
\text { model of cement was established to develop the contemporary } \\
\text { cement cycle of the United States [30]. }\end{array}$ & Cement & USA \\
\hline $\begin{array}{l}\text { This paper presents an evaluation of MFA to assess } \\
\text { construction and demolition (C\&D) debris generation and } \\
\text { composition in the USA. The results showed that C\&D debris } \\
\text { generation would exceed the previous prediction estimated by } \\
\text { other predictive methodologies and the more accurate the data } \\
\text { sources, the better the results will be [45]. }\end{array}$ & Construction/demolition debris & USA \\
\hline $\begin{array}{l}\text { Authors developed a comprehensive framework using MFA to } \\
\text { assess and calculate the transportation energy used for } \\
\text { recycling at the design stages of construction [27]. }\end{array}$ & Steel & Global and regional \\
\hline $\begin{array}{l}\text { A quantitative estimation model was developed to increase the } \\
\text { accuracy of construction waste estimation, which was based } \\
\text { on the mass balance principle, work breakdown structure, and } \\
\text { the consideration of four construction waste origins [10]. }\end{array}$ & $\begin{array}{l}\text { Quantitative construction waste } \\
\text { model }\end{array}$ & Tangshan \\
\hline $\begin{array}{l}\text { Lockrey et al. presented the practical challenges of recycling } \\
\text { C\&D waste in Vietnam and adopted MFA to analyze material } \\
\text { flows and recycling rates [47]. }\end{array}$ & Concrete & Vietnam \\
\hline $\begin{array}{l}\text { A method for the estimation of dense and heterogeneous } \\
\text { building stock was proposed, which considers the material } \\
\text { intensity and land occupation. Moreover, this study also } \\
\text { analyzes waste flows and predictions for its waste generation } \\
\text { in Rio de Janeiro using the MFA approach [46]. }\end{array}$ & Residential building stock & Rio de Janeiro \\
\hline $\begin{array}{l}\text { To improve the estimation accuracy of nonmetallic minerals, a } \\
\text { feasible method was proposed, which combined the } \\
\text { consumptions of bitumen, bricks, cement, and railways and } \\
\text { infers the actual yearly consumption of nonmetallic minerals } \\
\text { at national and global levels [31]. }\end{array}$ & Non-metallic minerals & global scale \\
\hline $\begin{array}{l}\text { Through an enhanced MFA at the Italian national level, a } \\
\text { functional-cognitive framework was proposed to evaluate the } \\
\text { current status of raw materials and waste production, and to } \\
\text { improve sustainable waste management within the entire } \\
\text { supply chain [28]. }\end{array}$ & Raw materials and waste production & Italy \\
\hline $\begin{array}{l}\text { A comparative MFA between Great Britain and Thailand for } \\
\text { cement/concrete materials was proposed to analyze the } \\
\text { different practices of the two countries [17]. }\end{array}$ & Cement/concrete & Britain, Thailand \\
\hline
\end{tabular}

From Table 2, except for some specific materials waste, it is recognized that researchers have achieved some effective assessment methods for mixed wastes, such as construction and demolition debris [45], non-metallic minerals [31], and raw materials and waste production [28]. Moreover, from Table 2, the location of the research is not limited to a small district, but ranging from a city, a country, many different countries, to a global scale. Through MFA, researchers can analyze the wide range of waste types within a wide geographical range, which also proves the flexibility and practicability of MFA regarding waste treatment. 


\subsection{Extension MFA}

MFA has had some new research developments in recent years and has provided some new features to the traditional MFA, such as dynamic material flow analysis, spatial material flow analysis, and continuous MFA.

\subsubsection{Dynamic Material Flow Analysis}

Dynamic material flow analysis has an obvious characteristic, different with MFA, which is that it considers a time span of years, or even decades. In dynamic material flow analysis, some historic data or historic development models of materials stocks and flows are utilized to evaluate the materials flow and stock in robust scenarios. For example, based on consumption data during 1900-2016, Wang et al. analyzed the current in-use copper stocks and predicted the amount of copper scrap generation until 2031 through dynamic material flow analysis [55]. Serrenho et al. used dynamic material flow analysis to design a stock dynamic flow model for England buildings to assess the embodied and operational emissions between new building constructions and existing building refurbishments [56]. Also using dynamic material flow analysis, $\mathrm{Hu}$ et al. analyzed the subsequent effects on the concrete consumption and concrete waste generation during house construction and demolition in Beijing's urban housing system from 1949 to 2050 [19]. They proposed that extending the lifetime of a house can delay the arrival of the C\&D waste peak, and C\&D waste recycling is strongly recommended for long-term, sustainable C\&D waste management [19]. A brief summary of some articles related C\&D waste is listed in Table 3, including the research description, time span, research object, and background research location.

Table 3. Summary and analysis of C\&D waste processing based on DMFA.

\begin{tabular}{lcc}
\hline \multicolumn{1}{c}{ Purpose and Description } & Time Span (Years) & Research Object \\
\hline $\begin{array}{l}\text { An analysis about the dynamics dwelling floor area and } \\
\text { material use was presented for Norway's residential stock } \\
\text { through dynamic material flow analysis (DMFA) [22]. }\end{array}$ & 1900-2100 & Dwelling stock \\
\hline $\begin{array}{l}\text { Based on the requirement of the stock of housing floor } \\
\text { area, Hu et al. utilized DMFA to analyze Beijing's urban } \\
\text { residential system and to investigate the subsequent } \\
\text { effects of C\&D waste and consumption of concrete in three } \\
\text { different scenarios [19]. }\end{array}$ & 1949-2050 & Concrete \\
\hline $\begin{array}{l}\text { DMFA was employed to explore the current and future } \\
\text { timber quantity in the residential buildings stock and } \\
\text { building demolition waste [24]. }\end{array}$ & 2012-2100 & Timber \\
\hline $\begin{array}{l}\text { Some construction materials containing engineered } \\
\text { nanomaterials (ENMs) were analyzed using DMFA to } \\
\text { evaluate the fate and end-of-life phase of ENM, including } \\
\text { the ENM use phase, waste collection, waste pretreatment, } \\
\text { treatment of residues, and recycling or disposal in Japan's } \\
\text { construction sector [48]. }\end{array}$ & 1981-2016 & Austria \\
\hline
\end{tabular}

\subsubsection{Spatial Material Flow Analysis}

Spatial material flow analysis models have been developed using the spatial allocation of material flows [26]. The relevant challenges regarding spatial material flow analysis have been studied from economic and environmental perspectives $[25,26]$. There is only one study about C\&D waste using spatial material flow analysis, in which two construction indicators and a network-based spatial material flow analysis are presented [25]. Vivanco et al. aimed to accurately describe waste flows, both in terms of mass and spatial attributes, and to allow for the verification of municipal solid waste management's sustainability performance according to the efficiency in converting waste into products and the required transport intensity [25]. 


\subsubsection{Continuous Material Flow Analysis}

Schiller et al. [49] presented a continuous MFA concept and a conceptual framework of continuous material flow analysis, which included traditional MFA and a reverse flow. This reverse flow includes the capturing of high-quality waste in deconstruction processing, the processing captured waste into recycling aggregates, and the mixing of these aggregates to new products. Schiller et al. aimed to assess and quantify the entire building material cycle by considering the conversion of bulk nonmetallic mineral into recycled aggregates [49].

\subsection{Combination Methods Based on MFA}

Through the material flow analysis of building materials, information can be acquired about the current/future reuse, stock, and waste disposal of C\&D waste. However, it is difficult to accurately analyze and quantify the exact impact of building materials on the environment and the economy. Therefore, many scholars combine MFA and other methods to achieve an accurate economic and environmental assessment, which further extends the MFA applications. One of typical combination applications is the integration of MFA and LCA methods $[2,11,18,53]$. Zhang et al. illustrated through the integration between MFA and LCA that the recycling of C\&D waste can generate the co-benefits of land use reduction and greenhouse gases mitigation [18]. Teh et al. developed a mixed-unit hybrid LCA to analyze recycled construction materials and used the merging of physical and monetary units of building materials industrial systems to provide a more accurate calculation of embodied carbon and to increase the accuracy of tracking material flows [2]. Heeren et al. proposed a new bottom-up building stock model to evaluate materials impacts at the building level by utilizing GIS data sets, along with MFA and LCA approaches, which provided more accurate data and a higher flexibility in the space and time scales than previous bottom-up building models [53]. Additionally, GIS was also integrated with MFA to demonstrate the spatiotemporal patterns of the material stocks and flows with the development of infrastructure. The high spatial resolution maps included the quantity and composition of waste flow, which could provide a decision-making basis for a municipal government and relevant enterprises in terms of site selection, capacity, cost allocation, and technology selection for demolition and construction waste collection and disposal [50]. There are some different combination approaches for $C \& D$ waste recycling and disposal, such as MFA combined with input-output analysis (IOA) [37], MFA combined with environmental life cycle costing (ELCC) [11], MFA combined with statistical entropy analysis [57], etc. A summary of related articles is listed in Table 4, including their research purposes and descriptions, research methods, objects, and research location scale.

We also found some of the same waste materials as research objects, but the processed methods were different, as shown in Table 5. Although some articles focused on the same waste material processing, authors had different purposes and application backgrounds. 
Table 4. Summary and analysis of C\&D waste processing based on combination MFA.

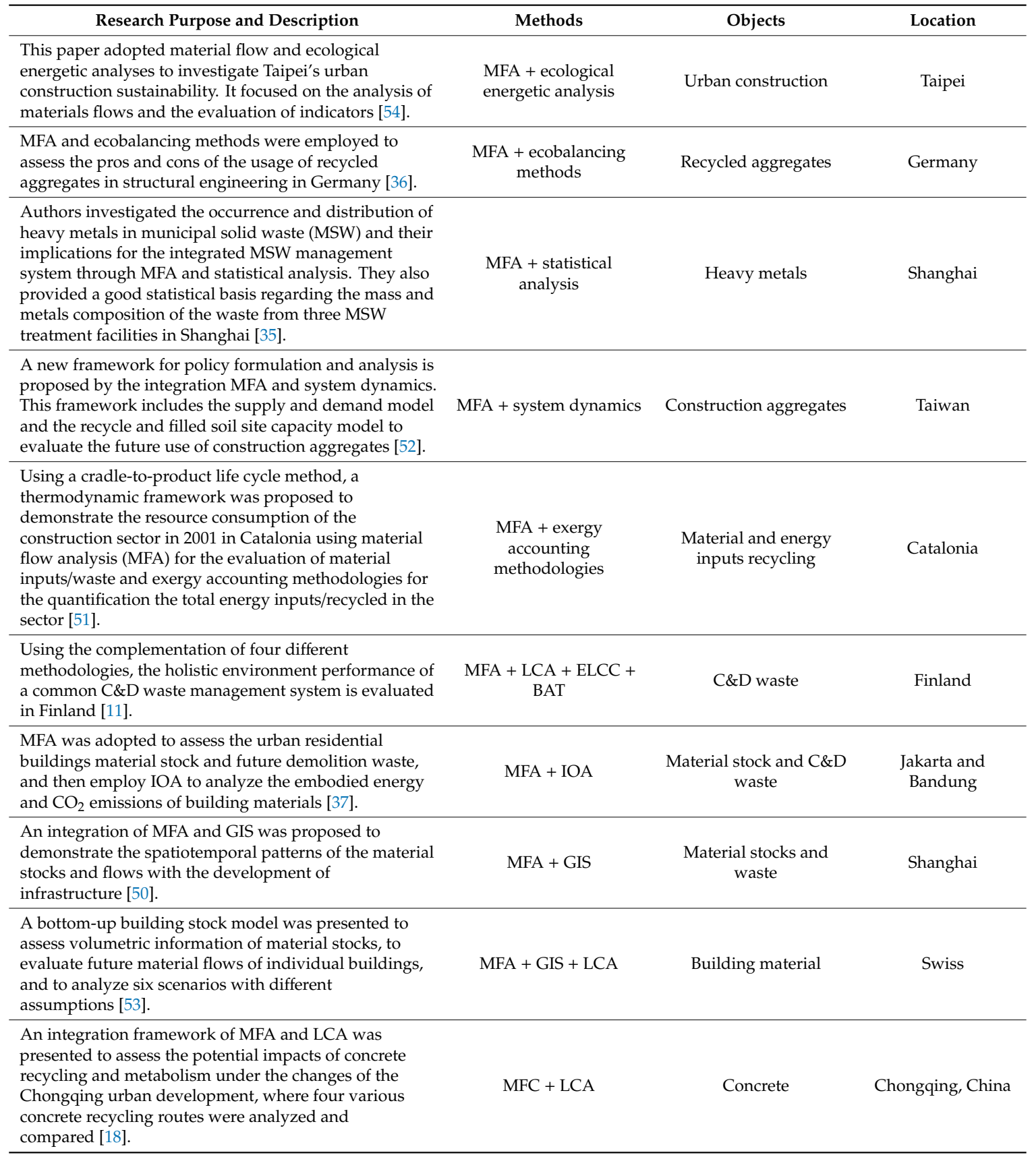

Note: LCA: Life Cycle Assessment; ELCC: environmental life cycle costing; BAT: best available technology; IOA: input-output analysis. 
Table 5. Statistics regarding special materials and research methods.

\begin{tabular}{ccc}
\hline Materials & Number of Articles & Methods and References \\
\hline Metal & 3 & MFA [14,27] \\
Aggregates & 3 & $\begin{array}{c}\text { MFA + ecobalancing methods [36] } \\
\text { MFA + system dynamics [52] } \\
\text { Continuous MFA [49] }\end{array}$ \\
\hline Cement/Concrete & & MFA [17,30,45,47] \\
& 7 & DMFA [19] \\
& & MFC + LCA [18] \\
& & MFA + IOA + LCA [2] \\
\hline Building Material Stocks and Waste & 4 & MFA + IOA [50] \\
& & MFA + GIS + LCA [53] \\
& & MFA [46] \\
\hline
\end{tabular}

\section{Conclusions}

Based on the above analysis, a few consensuses can be drawn from the some analyzed articles One of them is that the MFA validity can be improved by using comprehensive data sources and data accuracy $[14,45]$. However, some waste generation is sometimes ignored or indistinct, such as the wastage in the product manufacturing [45], transportation, storage, and installation stages [27]. Bertram et al. suggested the establishment of a public, open, central data bank to collect all available information about the generation and composition of wastes [14]. The second consensus is that some research recommended effective waste classification should be processed at the construction site, which can achieve emission reduction and effective waste recycling $[18,36,58]$. However, classification at the construction site could be an expensive and complicated process, which is limited by the classification technology's level, equipment level, workers' skill, waste type purity, processing time, site space, cost, etc. Additionally, it is clear that the potential of the recycling and reuse of C\&D wastes is not adequately exploited, and further efforts are urgent $[6,12,28]$, which include national policies and strategies $[17,28,42,44]$, effective analysis methods [12,39], waste processing technologies and management $[3,9,11]$, and so on.

This study analyzes the current MFA application research and developments based on C\&D waste processing, and summarizes the research methods, research objects, and application scale. We classify MFA research into three categories: traditional MFA, extension MFA, and combination MFA, and then, discuss their own specialties. From Table 5, it is noticed that the combination methods have received more attention. This is because C\&D waste management is a complex project, in which material flow analysis, energy evaluation, green gas emission evaluation, and cost are important analysis elements $[18,53,54]$. Moreover, in sustainable urban development, single element analysis may not provide an effective basis for existing policy improvement about $C \& D$ waste recycling and disposal. Therefore, the combination methods still constitute the mainstream research approach in C\&D waste processing and management.

However, the integration of multiple methods, multi-source data acquisition, and multi-source data processing may bring some new challenges. These may help to explain why current research articles and adopted combination methods tend to research a single specific material, and why research location is limited to within a city or a country. Therefore, extending research objects and research position scales in combination methods based on MFA can be a future research direction to provide broad wastes analysis and large-scale policy support.

Urban development is a dynamic process that encourages the exploration of urban C\&D waste management from a long-term and dynamic perspective. According to these analyzed articles, it can be found that current dynamic MFA research based on C\&D waste still focuses on just one waste 
material. Although considering some materials' life spans, such as 40 years for infrastructures, 38 years for wooden buildings, 39 years for non-wooden buildings, etc., Suzuki et al. [48] still concentrated on ENM flows, stocks, and waste processing. A research gap is found regarding utilizing dynamic MFA for mixed wastes processing and analysis. Mixed wastes consist of multiple components with different life spans and probability distributions, which will increase the difficulties of data collection and analysis. The difficulties of dynamic MFA for mixed waste is not ignored; nevertheless, its demand is also not ignored.

The next future research direction may be the integration other methods with dynamic MFA for $C \& D$ waste recycling and disposal. Dynamic MFA can quantify materials stocks and flows in a dynamical and long-term manner, but the economic and environmental impacts of these materials stocks and flows over certain time spans are ambiguous, which makes them worthy of further research.

Author Contributions: Resources, methodology, and data collection, D.G.; formal analysis and investigation, D.G. and L.H.; writing — original draft preparation, D.G.; writing—review and editing, D.G. and L.H.

Funding: This research received no external funding.

Acknowledgments: NTNU Open Access publishing funds covers the article processing charges.

Conflicts of Interest: The authors declare no conflict of interest.

\section{References}

1. Mokhlesian, S.; Holmén, M. Business model changes and green construction processes. Constr. Manag. Econ. 2012, 30, 761-775. [CrossRef]

2. Teh, S.H.; Wiedmann, T.; Moore, S. Mixed-unit hybrid life cycle assessment applied to the recycling of construction materials. J. Econ. Struct. 2018, 7, 13. [CrossRef]

3. Agamuthu, P. Challenges in sustainable management of construction and demolition waste. Waste Manag. Res. 2008, 26, 491-492. [CrossRef] [PubMed]

4. Eurostat. Generation of Waste by Economic Activity; Eurostat: Luxembourg, 2015. Available online: https: //ec.europa.eu/eurostat/web/environment/waste/main-tables (accessed on 27 October 2015).

5. Lu, W.S. Big data analytics to identify illegal construction waste dumping: A Hong Kong study. Resour. Conserv. Recycl. 2019, 141, 264-272. [CrossRef]

6. Zhang, Y.Z.; Lu, W.S.; Tam, V.W.; Feng, Y. From urban metabolism to industrial ecosystem metabolism: A study of construction in Shanghai from 2004 to 2014. J. Clean. Prod. 2018, 202, 428-438. [CrossRef]

7. Zeng, N.S.; Liu, Y.; Mao, C.; Kong, M. Investigating the Relationship between Construction Supply Chain Integration and Sustainable Use of Material: Evidence from China. Sustainability 2018, 10, 3581. [CrossRef]

8. Vondrackova, T.; Podolka, L.; Vostova, V. Handling construction waste of building demolition. In 9th International Scientific Conference Building Defects; Senitkova, I.J., Ed.; EDP Sciences: Ceske Budejovice, Czech Republic, 2018.

9. Kourmpanis, B.; Papadopoulos, P.; Moustakas, K.; Stylianou, M.; Haralambous, K.J.; Loizidou, M. Preliminary study for the management of construction and demolition waste. Waste Manag. Res. 2008, 26, 267-275.

10. Li, Y.S.; Zhang, X.Q.; Ding, G.Y.; Feng, Z.Q. Developing a quantitative construction waste estimation model for building construction projects. Resour. Conserv. Recycl. 2016, 106, 9-20. [CrossRef]

11. Dahlbo, H.; Bachér, J.; Lähtinen, K.; Jouttijärvi, T.; Suoheimo, P.; Mattila, T.; Sironen, S.; Myllymaa, T.; Saramäki, K. Construction and demolition waste management-A holistic evaluation of environmental performance. J. Clean. Prod. 2015, 107, 333-341. [CrossRef]

12. Markic, D.N.; Carapina, H.S.; Bjelic, D.; Bjelic, L.S.; Ilic, P.; Pesic, Z.S.; Kikanovicz, O. Using Material Flow Analysis for Waste Management Planning. Pol. J. Environ. Stud. 2019, 28, 255-265.

13. Cao, Z.; Liu, G.; Zhong, S.; Dai, H.; Pauliuk, S. Integrating Dynamic Material Flow Analysis and Computable General Equilibrium Models for Both Mass and Monetary Balances in Prospective Modeling: A Case for the Chinese Building Sector. Environ. Sci. Technol. 2019, 53, 224-233. [CrossRef] [PubMed]

14. Bertram, M.; Graedel, T.E.; Rechberger, H.; Spatari, S. The contemporary European copper cycle: Waste management subsystem. Ecol. Econ. 2002, 42, 43-57. [CrossRef] 
15. Gu, F. Exploring "Internet plus Recycling": Mass balance and life cycle assessment of a waste management system associated with a mobile application. Sci. Total Environ. 2019, 649, 172-185. [CrossRef] [PubMed]

16. Gonda, L.; D'Ans, P.; Degrez, M. A comparative assessment of WEEE collection in an urban and rural context: Case study on desktop computers in Belgium. Resour. Conserv. Recycl. 2019, 142, 131-142. [CrossRef]

17. Tangtinthai, N.; Heidrich, O.; Manning, D.A.C. Role of policy in managing mined resources for construction in Europe and emerging economies. J. Environ. Manag. 2019, 236, 613-621. [CrossRef] [PubMed]

18. Zhang, C.B.; Hu, M.M.; Dong, L.; Xiang, P.C.; Zhang, Q.; Wu, J.B.; Li, B.; Shi, S.Y. Co-benefits of urban concrete recycling on the mitigation of greenhouse gas emissions and land use change: A case in Chongqing metropolis, China. J. Clean. Prod. 2018, 201, 481-498. [CrossRef]

19. Hu, M.; van der Voet, E.; Huppes, G. Dynamic Material Flow Analysis for Strategic Construction and Demolition Waste Management in Beijing. J. Ind. Ecol. 2010, 14, 440-456. [CrossRef]

20. De Meester, S.; Nachtergaele, P.; Debaveye, S.; Vos, P.; Dewulf, J. Using material flow analysis and life cycle assessment in decision support: A case study on WEEE valorization in Belgium. Resour. Conserv. Recycl. 2019, 142, 1-9. [CrossRef]

21. Müller, D.B. Stock dynamics for forecasting material flows-Case study for housing in The Netherlands. Ecol. Econ. 2005, 59, 142-156. [CrossRef]

22. Bergsdal, H.; Brattebo, H.; Bohne, R.A.; Muller, D.B. Dynamic material flow analysis for Norway's dwelling stock. Build. Res. Inf. 2007, 35, 557-570. [CrossRef]

23. Soulier, M.; Chahoud, S.; Goldmann, D.; Espinoza, L.A.T. Dynamic analysis of European copper flows. Resour. Conserv. Recycl. 2018, 129, 143-152. [CrossRef]

24. Katcher, J.; Praxmarer, G.; Teischinger, A. Quantification of future availabilities of recovered wood from Austrian residential buildings. Resour. Conserv. Recycl. 2017, 123, 143-152. [CrossRef]

25. Font Vivanco, D.; Ventosa, I.P.; Durany, X.G. Building waste management core indicators through Spatial Material Flow Analysis: Net recovery and transport intensity indexes. Waste Manag. 2012, 32, 2496-2510. [CrossRef] [PubMed]

26. Roy, M.; GEllis; Curry, R. Spatial Allocation of Material Flow Analysis: A Geographic Information System Application of Material Flow Analysis in Ireland; Environmental Protection Agency: Dublin, Ireland, 2010.

27. Chong, W.K.; Hermreck, C. Modeling the use of transportation energy for recycling construction steel. Clean Technol. Environ. Policy 2011, 13,317-330. [CrossRef]

28. Luciano, A.; Reale, R.; Cutaia, L.; Carletti, R.; Pentassuglia, R.; Elmo, G.; Mancini, G. Resources Optimization and Sustainable Waste Management in Construction Chain in Italy: Toward a Resource Efficiency Plan. Waste Biomass Valorization 2018, 9, 1-13. [CrossRef]

29. Holzle, I. Analysing material flows of landfill mining in a regional context. J. Clean. Prod. 2019, 207, 317-328. [CrossRef]

30. Kapur, A. The contemporary cement cycle of the United States. J. Mater. Cycles Waste Manag. 2009, 11, 155-165. [CrossRef]

31. Miatto, A. Global Patterns and Trends for Non-Metallic Minerals used for Construction. J. Ind. Ecol. 2017, 21, 924-937. [CrossRef]

32. Fiore, S. Improving waste electric and electronic equipment management at full-scale by using material flow analysis and life cycle assessment. Sci. Total Environ. 2019, 659, 928-939. [CrossRef] [PubMed]

33. Norup, N. Evaluation of a European textile sorting centre: Material flow analysis and life cycle inventory. Resour. Conserv. Recycl. 2019, 143, 310-319. [CrossRef]

34. Lucchi, E.; Tabak, M.; Troi, A. The "cost Optimality" Approach for the Internal Insulation of Historic Buildings. Energy Procedia 2017, 133, 412-423. [CrossRef]

35. Zhang, H.; He, P.J.; Shao, L. MImplication of heavy metals distribution for a municipal solid waste management system-a case study in Shanghai. Sci. Total Environ. 2008, 402, 257-267. [CrossRef] [PubMed]

36. Weil, M.; Jeske, U.; Schebek, L. Closed-loop recycling of construction and demolition waste in Germany in view of stricter environmental threshold values. Waste Manag. Res. 2006, 24, 197-206. [CrossRef] [PubMed]

37. Surahman, U.; Higashi, O.; Kubota, T. Evaluation of current material stock and future demolition waste for urban residential buildings in Jakarta and Bandung, Indonesia: Embodied energy and CO2 emission analysis. J. Mater. Cycles Waste Manag. 2017, 19, 657-675. [CrossRef]

38. Wu, Z. Quantifying construction and demolition waste: An analytical review. Waste Manag. 2014, 34, 1683-1692. [CrossRef] [PubMed] 
39. Hassan, S.H.; Aziz, H.A.; Daud, N.M.; keria, R.; Noor, S.M.; Johari, I.; Shah, M.R. The methods of waste quantification in the construction sites (A review). In AIP Conference Proceedings; Amer Inst Physics: Penang, Malaysia, 2018.

40. Yeheyis, M.; Hewage, K.; Alam, M.S.; Eskicioglu, C.; Sadip, R. An overview of construction and demolition waste management in Canada: A lifecycle analysis approach to sustainability. Clean Technol. Environ. Policy 2013, 15, 81-91. [CrossRef]

41. Allesch, A.; Brunner, P.H. Material Flow Analysis as a Decision Support Tool for Waste Management: A Literature Review. J. Ind. Ecol. 2015, 19, 753-764. [CrossRef]

42. Umar, U.A. A review on adoption of novel techniques in construction waste management and policy. J. Mater. Cycles Waste Manag. 2017, 19, 1361-1373. [CrossRef]

43. Chen, J.; Su, Y.; Si, H.; Chen, J. Managerial Areas of Construction and Demolition Waste: A Scientometric Review. Int. J. Environ. Res. Public Health 2018, 15, 2350. [CrossRef]

44. Kylili, A.; Fokaides, P.A. Policy trends for the sustainability assessment of construction materials: A review. Sustain. Cities Soc. 2017, 35, 280-288. [CrossRef]

45. Cochran, K.M.; Townsend, T.G. Estimating construction and demolition debris generation using a materials flow analysis approach. Waste Manag. 2010, 30, 2247-2254. [CrossRef] [PubMed]

46. Condeixa, K.; Haddad, A.; Boer, D. Material flow analysis of the residential building stock at the city of Rio de Janeiro. J. Clean. Prod. 2017, 149, 1249-1267. [CrossRef]

47. Lockrey, S. Recycling the construction and demolition waste in Vietnam: Opportunities and challenges in practice. J. Clean. Prod. 2016, 133, 757-766. [CrossRef]

48. Suzuki, S. Modeling the fate and end-of-life phase of engineered nanomaterials in the Japanese construction sector. Waste Manag. 2018, 72, 389-398. [CrossRef] [PubMed]

49. Schiller, G.; Gruhler, K.; Ortlepp, R. Continuous Material Flow Analysis Approach for Bulk Nonmetallic Mineral Building Materials Applied to the German Building Sector. J. Ind. Ecol. 2017, 21, 673-688. [CrossRef]

50. Han, J. Uncovering the Spatiotemporal Dynamics of Urban Infrastructure Development: A High Spatial Resolution Material Stock and Flow Analysis. Environ. Sci. Technol. 2018, 52, 12122-12132. [CrossRef] [PubMed]

51. Hoque, M.R. Energy Intensity of the Catalan Construction Sector: An Application of Material and Exergy Flow Analysis. J. Ind. Ecol. 2012, 16, 699-709. [CrossRef]

52. Hsiao, T.Y.; Yu, Y.H.; Chang, I.C. Material flows analysis of construction aggregates in Taiwan. Prog. Ind. Ecol. 2009, 6, 135-152. [CrossRef]

53. Heeren, N.; Hellweg, S. Tracking Construction Material over Space and Time: Prospective and Geo-referenced Modeling of Building Stocks and Construction Material Flows. J. Ind. Ecol. 2019, 23, 253-267. [CrossRef]

54. Huang, S.L.; Hsu, W.L. Materials flow analysis and emergy evaluation of Taipei's urban construction. Landsc. Urban Plan. 2003, 63, 61-74. [CrossRef]

55. Wang, M.X. Dynamic analysis of copper consumption, in-use stocks and scrap generation in different sectors in the US 1900-2016. Resour. Conserv. Recycl. 2018, 139, 140-149. [CrossRef]

56. Serrenho, A.C. Testing the greenhouse gas emissions reduction potential of alternative strategies for the english housing stock. Resour. Conserv. Recycl. 2019, 144, 267-275. [CrossRef]

57. Martinez, O. Statistical entropy analysis as tool for circular economy: Proof of concept by optimizing a lithium-ion battery waste sieving system. J. Clean. Prod. 2019, 212, 1568-1579. [CrossRef]

58. Yuan, H.; Lu, W.; Hao, J.J. The evolution of construction waste sorting on-site. Renew. Sustain. Energy Rev. 2013, 20, 483-490. [CrossRef]

(C) 2019 by the authors. Licensee MDPI, Basel, Switzerland. This article is an open access article distributed under the terms and conditions of the Creative Commons Attribution (CC BY) license (http://creativecommons.org/licenses/by/4.0/). 